\title{
UNIVERSIDADE, CULTURA E DIREITO ROMANO
}

\author{
José Carlos Moreira Alves \\ Professor Titular do Departamento de Direito Civil \\ da Faculdade de Direito da Universidade de São Paulo \\ Ministro do Supremo Tribunal Federal
}

Resumo:

O artigo examina a universidade, suas origens, faz um breve relato histórico e a seguir trata do ius ubique docendi que significava a autonomia, vigorante na Idade Média. Aborda mudanças advindas do Iluminismo e da Reforma Protestante, o abandono da universitas scientiarum e a passagem da universidade para um conjunto de escolas superiores reunidas.

Discute a seguir os fins da universidade e as diferentes visões acerca deles, os problemas relativos à transmissão da cultura, da investigação científica, transmissão do saber e do ensino dos professores.

Analisa o estudo do Direito Romano, as pesquisas acerca do corpus iuris civilis, desde a Idade Média até os dias atuais, as glossas, o mos italicus e o mos gallicus. As visões medieval e moderna do estudo do Direito Romano e seus reflexos na Europa e no Brasil. Finaliza salientando a importância do estudo do Direito Romiano e do latim para a manutenção da cultura de base greco-romana.

Abstract:

The article examines the university, its origins; it makes a brief historic report and after that deals with the ius ubique docendi that meant autonomy, in force during the middle ages. It shows changes resulting from Illuminism and from the Protestant Reform, the abandonment of the universitas scientiarium and the transformation of the university into a group of colleges together.

It discusses after that the goals of the university and the different views about them, the problems connected to the transmission of culture, scientific investigation, transmission of knowledge and of the teaching of the professors.

It analyses the study of Roman Law, the research about the corpus iuris civilis, from the middle ages up to the present days, the glossas, the mos italicus and the mos gallicus. The medieval and modern views of the study of the Roman Law and its reflexes in Europe and in Brazil. It ends by highlighting the importance of the study of Roman Law and Latin for the preservation a culture based in Rome and Greece. 
Sumário:

1. A universidade das origens à atualidade.

2. Os fins a que visa a universidade.

3. A universidade e o estudo do direito romano.

4. Universidade, direito romano e formação cultural.

\section{A UNIVERSIDADE DAS ORIGENS À ATUALIDADE.}

As escolas que existiram na Antigüidade e na Alta Idade Média não chegaram a constituir universidades.

A universidade é criação da Baixa Idade Média. Surge no século XII como corporação de mestres e de alunos (universitas magistronum et scholarium), não sendo, como virá a ser, um conjunto de escolas superiores, mas nascendo de uma escola local ou da fusão de escolas locais que se projetam universalmente, institucionalizando-se pelo espírito corporativo que as anima. ${ }^{1}$ Seu aparecimento se deve à conjugação de várias causas, de que as principais assim foram sintetizadas por Braga da Cruz: "o progresso geral do saber; o rápido incremento de certas disciplinas, como a teologia científica, o direito romano $e$ o direito canônico; um novo sentido da unidade da ciência e uma noção mais rigorosa da hierarquia entre os vários ramos do saber humano; o movimento europeu da formação dos grandes centros urbanos; o sentimento de solidariedade

1. A propósito escreve Fernando de Azevedo (As universidades no mundo futuro, Rio de Janeiro, 1944, p. 35 e ss.):

"Na Idade Média, de fato, o mesmo espírito de associação que deu ao ofício sua fisionomia corporativa (toda corporação de oficio é uma 'universidade') presidiu também ao desenvolvimento do comércio e das universidades no sentido intelectual, as quais não passavam de associaçōes de doutores $e$ de estudantes ('universitas scholarium et magistrorum'), organizadas para darem $e$ receberem lições - coletividades constituidas em pessoa civil e estruturadas segundo o modelo, que então se generalizou, das corporações medievais.

Submetidas a um enquadramento mais ou menos rigido, essas altas escolas em que se ministrava a cultura superior da época, fundada sobre as sete artes liberais ('studia generalia') $e$ constituida das disciplinas especiais, medicina, cânones e leis, e teologia, multiplicaram-se em exemplares por quase toda a Europa e a partir do século XV, por algumas regiōes da América, mas sem perderem em suas linhas mestras a estrutura original sob que se acusavam, de país para país, mentalidades $e$ orientaçōes variáveis com os temperamentos nacionais $e$ as diferenças nas tendências de suas respectivas culturas". 
profissional que inspira a formação das grandes corporações de artes e oficios".2 Nos séculos XII e XIII, tanto as que surgem de modo espontâneo pela projeção universal que ganham escolas locais pela fama de seus mestres ou pela especialização em algum setor do saber humano, quanto as que decorrem do desdobramento de outras já existentes ou de ato de um monarca cuja confirmação pelo Papa dava projeção universal pelo reconhecimento do ius ubique docendi (direito de ensinar onde quer que seja) resultante do grau acadêmico por elas conferido, desfrutam de total autonomia nos planos jurídico, administrativo e intelectual. Sua direção, em algumas, se enfeixa preferentemente nos professores, e em outras, nos alunos, não se subordinando aos soberanos nem aos papas. Sua independência intelectual decorre da crença católica que é a única vigorante; da não-sujeição política; da orientação de ensino que livremente escolheu. Esse panorama se modifica parcialmente nos séculos XIV e XV. O renascimento do direito romano, devido principalmente à universidade, foi um dos fatores preponderantes do fortalecimento do poder real, que progressivamente vai interferindo nela, diminuindo-lhe gradualmente a autonomia jurídica e administrativa de que gozava. Essa subordinação ao monarca vincula a universidade aos interesses políticos nacionais, mas não the retira o caráter universal das disciplinas que ensina e que possibilita a permanência do ius ubique docendi -, nem lhe restringe a liberdade de doutrina, não se arvorando o Estado em impor-lhe orientação nesse terreno. A par disso, o humanismo, que começa a surgir no século XIV, influi no sentido de que a universidade admita novas disciplinas científicas que não se vinculam à preparação imediata para o exercício profissional. Com a Reforma protestante, no século XVI, a liberdade intelectual da universidade sofre severo golpe. $\mathrm{O}$ cisma religioso repercute nela, quer nos Estados que aderem ao movimento reformista, quer nos que permanecem fiéis ao poder espiritual do Papa. Naqueles, a interferência é maior, repercutindo, para a implantação do protestantismo, no elenco de disciplinas e na orientação doutrinária. Com a ruptura religiosa, deixa de existir o caráter universal do ensino universitário, perdendo o ius ubique docendi sua razão de ser pela diversidade do ensino

2. Origem e evolução da universidade. In: Obras esparsas: estudos doutrinários e sociais, Coimbra, 1985, v.4, p. 194-5. 
universitário entre os Estados católicos e os protestantes, variando também nestes, conforme a seita acolhida. Se, porém, no século XVII, não há diferença maior entre o ensino universitário de um país católico e o de outro, pois a universidade ainda visa a servir à comunidade católica, já no século XVIII isso não ocorre mesmo nesses países. É ele o século das reformas universitárias que o despotismo esclarecido e a Revolução Francesa fizeram, influenciados pelo iluminismo e pelo utilitarismo. É nesse período que a universidade perde sua índole universal, passando a ter o caráter de instituição nacional. A reformulação do ensino universitário não é, porém, feita pela própria universidade, mas imposta pelo Estado, que interfere na liberdade intelectual que nela ainda existia nos países católicos. É o Estado que, então, estabelece o rol das disciplinas universitárias, fixa as diretrizes doutrinárias, determina a orientação pedagógica contrária à especulação e eminentemente utilitarista, impõe o método de ensino a ser seguido. Com a Revolução Francesa, que laiciza o ensino, enraiza-se o entendimento de que ele deve ser prestado pelo Estado e estar a seu serviço. Essa concepção passa para o Estado liberal do século XIX, que, sob a égide do utilitarismo, do positivismo e do materialismo, coloca em primeiro plano as disciplinas de imediata utilidade prática, pondo, em segundo, as especulativas. Com isso, deixa a universidade de ser a universitas scientiarum que era, por se haver perdido o sentido da unidade da ciência, e se transforma ela num conjunto de escolas superiores reunidas mecanicamente uma ao lado da outra, passando a criar técnicos em determinado ramo do saber. No século que corre, essa característica persiste, a ponto de levar Gilberto Freire a advertir:

"Não se limita a missão das Universidades a formar profissionais. Ou especialistas. Ou em requintar-se em produzir Ph. D.D. por mais perfeitos nos seus especialismos: Ph. D.D. que estão antes empobrecendo que enriquecendo a atual cultura universitária dos Estados Unidos com a sua quase nenhuma criatividade, 
tal a sua erudição especializadíssima. Elitismo do mau. Do péssimo". ${ }^{3}$

\section{OS FINS A QUE VISA A UNIVERSIDADE.}

A missão da universidade é alcançar, obviamente, da melhor forma possível, os fins a que ela visa.

Quais são esses fins?

Escrevendo sobre a missão da universidade, observou Ortega Y Gasset ${ }^{4}$ que o ensino universitário, nos tempos modernos, visa a preencher três funções:

a - a transmissão da cultura;

b - o ensino das profissões; $\mathrm{e}$

c - a investigação científica e educação de novos homens de ciência.

Mais tarde, na década de sessenta, escrevendo sobre o problema da universidade, salientou Braga da Cruz que não havia dificuldade para se ter uma idéia clara e rigorosa dos fins dessa instituição, e isso porque, dizia ele,

"... nenhum pensador hoje em dia seriamente contesta - seja ele católico, liberal ou comunista - que são três os fins primordiais que a Universidade se deve propor: formação cultural dos futuros dirigentes da Sociedade e da Nação; transmissāo do saber, com vista à preparaçāo para o exercício das profissões intelectuais de grau mais elevado; investigação científica e preparaçâo de futuros investigadores, com vista ao progresso da própria ciência que lhe cumpre transmitir às novas gerações". 5

3. Prefácio do livro Omissão da universidade?, de autoria de José Carlos de Almeida Azevedo, Rio de Janeiro, 1978, p. 16.

4. El libro de las misiones, $5^{\mathfrak{a}}$ ed., Buenos Aires, México, 1950, p. 70.

5. O problema da universidade. In: Obras esparsas...ob. cit., v.4, p. 315. 
No decurso da história da universidade, verifica-se que ela nunca chegou a ser exclusivamente cultural, ou só técnica, ou apenas científica. Em geral, porém, não tem havido equilíbrio entre esses fins, mas preponderância de um ou de alguns.

$\mathrm{Na}$ universidade medieval, prepondera o objetivo do ensino para a preparação de profissionais, sem se descuidar, todavia, do relativo à formação cultural, porquanto, como acentua Stephen D'Irsay, "para o homem medieval o que mais importava era a aquisição de uma sólida 'Weltanschauung', uma visão de conjunto do mundo, não havendo essa adoração dos fatos pelos fatos que o homem moderno, ainda que intelectual, tem; ora, para a aquisição dessa compreensão do universo, o método universitário, com seus cursos logicamente encadeados e construídos, dava um meio ideal" ${ }^{6}$

Com o surgimento, no século XIV, do humanismo, caracterizado pelo interesse do conhecimento da Antigüidade Clássica, deu-se mais ênfase à formação cultural, porque o estudo das humanidades se fundava na concepção, favorável às disciplinas especulativas, do cultivo da arte pela arte, sem o proveito do imediatismo utilitarista. Continuou a prevalecer, porém, o objetivo da preparação profissional. No campo do direito, o resultado da influência do humanismo sobre a universidade foi o aparecimento, na Renascença, da Escola dos Cultos, que reagiu à dos Bartolistas, contrapondo o mos gallicus ao mos italicus. Com a Reforma protestante, as universidades, conforme fossem protestantes ou católicos os Estados a que elas se encontravam vinculadas, se colocaram a serviço daquela ou da Contra-Reforma, o que dificultou o acolhimento, pela maioria delas, do ensino das ciências naturais. É no século XVII que o estudo científico encontra guarida nas universidades ao lado das disciplinas tradicionais. A princípio, as universidades se ocuparam apenas com o ensino dessas ciências, mas a partir do século XVIII, na missão delas se vai incluir, pouco a pouco, a investigação científica. Nesse mesmo século, porém, por influência do iluminismo e mais tarde da Revolução Francesa, se amplia a missão da universidade para abarcar, como um de seus fins, a investigação científica; por outro lado se coloca em plano secundário o da formação cultural, com a preponderância que se deu às disciplinas de imediato interesse material 
em detrimento das especulativas e formativas. O século das luzes, como foi chamado o século XVIII, considera que o homem deve esforçar-se precipuamente para o conhecimento e domínio da natureza. A preparação de técnicos e a investigação científica passam a ser os fins primordiais da universidade. Essa orientação persiste no século XIX, e é justificada, no terreno do ensino universitário jurídico, pelo positivismo, de que decorreu o dogmatismo jurídico, anti-historicista por excelência: deveria o jurista somente estudar as normas vigentes, para delas retirar, por indução, os conceitos gerais em que se estriba o direito positivo, estabelecendo, então, dedutivamente suas conseqüências, e formando, assim, um sistema lógico de categorias abstratas. Já na centúria em que vivemos e que se aproxima de seu término, não têm faltado vozes prestigiosas em favor da revalorização de um dos fins da universidade - a formação cultural, para retirá-la do plano secundário èm que muitos ainda insistem em colocá-la, empolgados pelo vertiginoso progresso material dos tempos modernos, mas esquecidos de que a crise do mundo contemporâneo é, em última análise, uma crise espiritual, para a qual, de alguma forma, concorreu a universidade quando passou a dedicar-se precipuamente à criação de técnicos. Há mais de meio século, escrevia Leonel Franca estas palavras, que continuam atuais:

"Para a organização da vida social o homem moderno não conta senão com bens econômicos $e$ técnicos aperfeiçoados para produzi-los. Mas bens materiais puros não podem constituir o cimento de uma convivência pacífica e fraterna. Quem os não possui deseja-os e deseja-os sempre mais; quem os alcançou esforça-se para excluir os outros de seu gozo. Um mundo regido só pelo apetite dos frutos da terra tende com todo o seu peso para um caos de ódios, de discórdias fraticidas: 'bellum omnium contra omnes'. Conflitos de egoismos isolados, entrechoques de egoismos coletivos. Homem contra homem, classe contra classe. Sobre a multiplicidade informe e confusa dos bens da matéria é mister que paire a força 
ordenadora do espirito: o direito com a universalidade dos seus preceitos, a justiça com a inviolabilidade de suas exigências, o amor com a generosidade de suas aspirações".7

Nessa linha de pensamento, Ortega Y Gasset, escrevendo sobre a missão da universidade nos tempos modernos, acentuou que era preciso humanizar o cientista, para que ele deixasse de ser o que ocorria com deplorável freqüência: "um bárbaro que sabe muito de uma coisa". ${ }^{8} \mathrm{Em}$ seu entender, das três funções que a universidade deveria exercer, sobrelevava a da formação cultural, e isso porque, em suas palavras, ela "iem de fazer do homem médio, antes de tudo, um homem culto - situá-lo à altura dos tempos; portanto, a função primária e central da Universidade é o ensino das grandes disciplinas culturais". ${ }^{9}$ Menos radical, mas não menos incisivo em favor da defesa dessa função da universidade, é Braga da Cruz, ao examinar $O$ problema da universidade. Partindo, também, dos três fins a que visa ela, conclui ele que "a Universidade será tanto mais universitária quanto mais equilibradamente souber e puder preencher cada um dos seus fins sem prejuizo dos demais" ${ }^{10}$ porquanto:

"É, aliás, muito discutivel se a Universidade, desprezando algum dos fins que lhe pertencem, poderá ficar servindo melhor os restantes, a pretexto de, assim, ter concentrado na respectiva prossecução todas as suas energias. É o caso de perguntar, designadamente, quem será melhor profissional: se aquele que aprendeu a maior soma possivel de conhecimentos técnicos para o exercício duma profissāo, mas sem qualquer cultura de base e sem espírito científico, ou aquele que adquiriu uma boa formação cultural e o gosto de enfrentar e

7. A crise do mundo moderno, $2^{\mathrm{a}}$ ed., Rio de Janeiro, 1942, p. 290.

8. Ob. cit., p. 102.

9. Ibid., p. 83.

10. O problema...ob. cit., v.4, p. 317. 
resolver problemas, a alicerçar um conhecimento algo mais modesto de conhecimentos especializados sobre a profissāo que exerce. E o mesmo se pergunta, 'mutatis mutandis', a respeito de quem na Universidade nada mais tivesse recebido senão formação cultural ou nada mais tivesse contemplado senão investigação científica. Nem o primeiro seria verdadeiramente um homem culto $e$ bem formado, nem o segundo chegaria algum dia a ser um autêntico investigador".11

\section{A UNIVERSIDADE E O ESTUDO DO DIREITO ROMANO.}

A necessidade do estudo universitário do direito romano nem sempre esteve em debate. Ao contrário, durante séculos não foi ela discutida, embora tivesse variado a orientação de seu ensino, que, por vezes, em alguns lugares, chegou a ser proibido ou rejeitado, por motivos

As dúvidas e os ataques relativos a essa necessidade surgem no século XIX com as codificações modernas que ab-rogam o que do direito romano se encontrava vigente, e persistem, com maior ou menor intensidade, neste século.

Ao longo da história, como observa Koschaker, ${ }^{12}$ o direito romano esteve intimamente ligado à universidade.

De início, pela dificuldade que apresentava a utilização prática do Corpus Iuris Ciuilis, foi necessário o estudo aprofundado dessa compilação, não só para aclarar suas obscuridades, mas também para aproximar as passagens paralelas ou semelhantes, revelando, inclusive, as antinomias, e tentando dar-lhes solução. Esse trabalho só se poderia fazer em centros de estudo e de saber como eram as universidades. Seus artífices foram os glosadores, denominação que lhes adveio do uso das glosas aos textos romanos, pelas quais, principalmente, alcançaram o difícil objetivo a que se propuseram. Foram eles que transformaram uma modesta escola de artes existente em Bolonha, no final do século X, na Universidade de Bolonha, dedicada precipuamente ao estudo do

11. O problema...ob. cit., v.4, p. 318.

12. Europa und das Romische Recht, Müchen und Berlin, 1953, p. 67. 
direito romano, e que, em pouco, adquiriu fama de tal ordem que atraiu grande número de estudantes de outros países, para os quais, em sua volta, traziam os conhecimentos ali adquiridos. Esse estudo cujo resultado teve um caráter científico, datando daí, como observou Engelmann ${ }^{13}$ o início da ciência jurídica do mundo ocidental não teve finalidade meramente especulativa, mas visou, com a aplicação prática do direito romano que defluía do Corpus Iuris Ciuilis, a atender a exigências sociais, econômicas e especialmente políticas existentes na Baixa Idade Média. Nos meados do século XIII, Acúrsio compõe a Magna Glossa, também denominada Glossa Ordinaria ou simplesmente Glossa, compilação das glosas feitas ao Corpus Iuris Ciuilis pelos seus antecessores. Essa obra, que é o sintoma da decadência da Escola dos Glosadores, teve larga aceitação, e adquiriu enorme autoridade na prática jurídica e no ensino do direito, o que estreitou as relações entre a teoria e a prática, dando ensejo ao surgimento de novo método para o estudo do direito romano.

Aos glosadores sucedem os pós-glosadores ou comentaristas, que abandonam o método da interpretação literal do Corpus Iuris Ciuilis adotado pelos glosadores e criam a doutrina jurídica sistematizada, utilizando-se, para essa sistematização, da escolástica. O estudo do Corpus Iuris Ciuilis pelos glosadores tinha, também, sentido prático, porque consideravam eles que o direito romano justinianeu era direito aplicável, mas não levaram em conta a dificuldade da sua aplicação pela vigência de outras fontes jurídicas como o costume, o direito estatutário fundado no direito germânico e o direito canônico. Para vencer essa dificuldade, os pós-glosadores adotam outra orientação de estudo o mos italicus, por ter sido a Itália onde surgiu e mais se desenvolveu, para daí propagar-se por outros países. Em forma principalmente de comentários, em que atentavam também para as fontes jurídicas locais e examinavam a casuística, esforçaram-se os pós-glosadores em dar organicamente a exegese dos diversos títulos do Corpus Iuris Ciuilis - examinados não diretamente mas por intermédio das glosas -, procurando extrair deles princípios e teorias que se ajustassem às necessidades práticas de sua época. Com isso, o direito romano a aplicar-se na prática não é o que decorre do estudo direto do

13. Die Wiedergeburt der Rechtskultur in Italien durch die wissenschafiliche Lehre, Leipzig, 1939 , p. 16 e ss. 
Corpus Iuris Ciuilis, mas o que resulta da interpretação da Glossa e da opinião dos comentários dos doutores, cuja autoridade crescia de ponto quando se formava, entre eles, a communis opinio. Dessa atividade criadora dos pósglosadores resultou um direito romano ajustado às necessidades econômicosociais da vida medieval - o ius commune, destinado, na medida do possível, a substituir os costumes locais, cuja diversidade dava margem a litígios. Sua aplicação não se cinge à Itália, mas se alastra pela Europa culta. Com essa orientação, que visa a finalidades práticas, é o direito romano ensinado nas universidades, do século XIV ao XVI.

No século XVI, em decorrência do renascimento dos estudos clássicos, nova orientação se imprime ao estudo do direito romano pelos juristas que integram o que se denominou Escola Culta. Embora surgida na Itália, é principalmente na França que esse movimento se desenvolve. Nesse país, havia a idéia de que o direito romano se introduzira, por atuação dos legistas dos séculos XIII e XIV, não como ius scriptum, mas, em decorrência de suas qualidades intrínsecas, como ratio scripta, a facilitar a compreensão do direito nacional e a integrá-lo, suprindo suas lacunas. Daí, a aceitação dessa nova Escola, que deixa de lado a interpretação da Glosa e o método dos comentaristas, e se dedica ao estudo das fontes romanas, com o auxilio da filologia e da história. Inicia-se, assim, o estudo histórico do direito romano, com a investigação e a análise das modificações que seus institutos jurídicos sofreram ao longo de sua evolução. Em oposição à orientação italiana o mos italicus - surge, como vertente do humanismo, o mos gallicus. Embora essa nova orientação não se tenha adstringido à França, pois floresceu, também, na Alemanha, na Bélgica, na Espanha e até na Itália, o certo é que, mesmo na França, o mos gallicus não conseguiu desbancar o mos italicus, que continuou a ser seguido em centros importantes, como Toulouse. Na Itália, onde o surto humanista se havia iniciado, o ensino universitário do direito romano continua a observar o mos italicus. $\mathrm{Na}$ Alemanha, o mos gallicus, seguido pelos muitos professores franceses que ensinavam em suas universidades, não chegou, porém, a predominar. A Escola Culta, nas universidades em que dominou, imprimiu caráter científico ao estudo do direito romano, pois se dispôs a conhecê-lo pelo simples amor desse conhecimento, sem objetivar qualquer valor prático, cavando, assim, um fosso entre a teoria e a prática, acabando por contribuir para o desprestígio do Corpus 
Iuris Ciuilis, em virtude das críticas que the fez com o descobrimento das interpolações justinianéias. No século XVII, declina a influência desse movimento, exceto na Holanda, onde mantém seu prestígio, e onde os humanistas não se limitam ao estudo histórico do direito romano, mas têm em vista sua utilização prática, sem os excessos dos comentaristas, como se vê na obra de Voetius. O mos italicus, porém, persiste. Na Alemanha, no início dessa centúria, começa a expandir-se o brocardo quidquid non agnoscit glossa nec agnoscit curia, a significar que as partes do Corpus Iuris Ciuilis que não houvessem sido glosadas não eram aplicadas pelos tribunais; e, na segunda metade do século, começa a ser usada a expressão usus modernus Pandectarum como denominação do direito comum utilizado pelos alemães. ${ }^{14}$ Para a decadência da Escola Culta vários fatores conspiraram: o exagero das sutilezas e das minúcias especialmente de natureza filológica, em que incidiram muitos de seus adeptos, fez avolumar-se a crítica de que eram eles antes antiquários do que juristas; o propósito dessa Escola de libertar a prática forense da autoridade da communis opinio doctorum com o estabelecimento, pelo estudo das fontes romanas, de doutrinas jurídicas mais justas e racionais esbarrou com a resistência da própria praxis, que se adaptava melhor ao mos italicus; e a reação que começou a surgir contra a demasiada preferência que se dava ao direito romano, nas universidades e no foro, em detrimento dos direitos nacionais.

No século XVIII, a Escola do Direito Natural passa a encarar o direito romano sob nova ótica. Como, para os jusnaturalistas, o que importava era o direito que resultava diretamente da razão direito uno, imutável e eterno, que, portanto, não se formava historicamente, o direito romano só não sofre golpe mais profundo, porque serve ele, para os seguidores dessa corrente, que

14. Vide, a propósito, Sohm-Mitteis-Wenger, Institutionen (Geschichte und System des Romischen Privatrechts), Berlim, 1949, p. 151, notas 2 e 3.

Sobre o que se entendia a respeito do 'usus modernus Pandectarum', escreve De Diego (Introducción al estudio de las institutiones de derecho romano, Madrid, 1900, p. 361):

"... lo que bajo el nombre de 'usus modernus Pandectarum' se aplicaba en la práctica y se ensiñaba en la teoría, era una concordancia de disposiciones tomadas del Derecho romano, del germano, del canónico, de genuinamente alemán y delas sentencias de los tribunales; pero concordancia hecha sin principios, en la que no estaba clara la procedencia de cada una de ellas y se confundian y mesclaban las de Derecho romano y alemán, y muchas, fundadas sobre errores y malas inteligencias, pasaban como jurídico-romanas." 
assim, Grócio, Puffendorf, Henrique e Samuel Cocceio, Wolff dele eram grandes conhecedores, como o complexo de normas de que se extraíam os princípios que eram considerados conforme a razão, expurgando-se os em que isso não ocorria. Já Leibniz assinalara as relações entre o direito romano e o direito natural, realçando as virtudes dos juristas romanos, mas destacando os defeitos do direito que eles construíram, com a advertência, porém, de que, reduzindo e corrigindo, seria possível descobrirem-se nele os princípios do direito natural. Essa idéia foi recolhida pelos jusnaturalistas do século XVIII e concretizada nos códigos dos fins dessa centúria e do início da seguinte. Por ser o direito romano o elemento material de que se serviram os jusnaturalistas para revelarem os princípios do direito natural, que, de outra parte, agia como parâmetro de aferição das normas daqueles que mereciam persistir por se coadunarem com os preceitos da razão natural, ambos esses direitos sofreram influência recíproca, o que explica a permanência, no direito privado moderno, de princípios e de institutos jurídicos que de romanos têm apenas a forma, pois sua concepção é jusnaturalista. Daí poder dizer-se que o direito moderno herdou dos jusnaturalistas não-somente a sistematização do direito privado por eles introduzida, mas também os conceitos que elaboraram e que deu como resultado, no século XIX, a denominada jurisprudência dos conceitos. A Escola do Direito Natural, embora não repudiando o direito romano, abalou a confiança em sua excelência e determinou o aparecimento dos códigos modernos, frutos dessa depuração das normas jurídicas romanas. Nas universidades, continua o direito romano a ser ensinado, embora, em decorrência das reformas pedagógicas de que esse século foi fértil, tenha ele cedido terreno em favor dos direitos nacionais. Expressiva nesse sentido é a Reforma Pombalina na Universidade de Coimbra, inspirada no iluminismo de Verney, pela qual, no tocante ao ensino jurídico, se atacou a predominância do direito romano, o método escolástico e a irrestrita obediência à communis opinio doctorum, dando-se ênfase ao estudo do direito português, até então inexistente no currículo universitário, e realçando-se que a aplicação do direito romano se faria em conformidade com o seu uso moderno, e, conseqüentemente, como observado pela doutrina e pela legislação das nações cristãs.

No século XIX, acentua-se o processo de desgaste do prestígio dos estudos universitários de direito romano. Onde se editava um Código Civil, 
deixava o direito comum de ser direito positivo, e, com isso, perdia o direito romano ponderável parcela de interesse prático. Ademais, em decorrência do movimento codificador, esse século é fortemente impregnado pelo positivismo, de que resultou o dogmatismo jurídico, carregado de anti-historicismo. Assim, na França, depois da promulgação do Código Civil em 1804, começou a questionarse a utilidade do estudo e do ensino do direito romano. Em 1837, Bravard Veyrières, professor na Faculdade de Direito de Paris, escreve, a propósito, livro - De l'étude et de l'enseignement du droit romain et des résultats qu'on peut en attendre - que revela a extensão e a força alcançadas por esse questionamento, assim sintetizado:

" $O$ direito romano não tendo mais força de lei entre nós, não estando mais em relação, em harmonia, com os costumes e a civilização, é hoje uma questão controvertida, na Escola e no foro, saber que gênero de utilidade o estudo o o ensino desse direito podem ainda oferecer entre nós, e qual seria o melhor caminho a seguir para ensiná-lo". 15

E, depois de indagar retoricamente se haverá algum espírito isento de prevenções que não lhe dê razão em dizer que toda a utilidade que se pode "retirar do estudo do direito romano, considerado como meio de se formar na arte do raciocínio e da interpretação das leis, em uma palavra, de adquirir as qualidades essenciais ao jurisconsulto, se reduz a uma espécie de 'ginástica intelectual', menos própria, em verdade, a fortalecer o espírito e a esclarecê-lo, do que a fatigá-lo e a desencorajá-lo", ${ }^{16}$ procura demonstrar a verdade dessa proposição com exemplos, que traz ao longo da obra, da obscuridade dos textos romanos, da inadequação de vários deles aos tempos modernos, da sutileza de outros que quase chega ao ridículo, das idéias absurdas que neles abundam, da impossibilidade de justificar racionalmente alguns de seus costumes e instituições, do contraste entre o direito público de Roma e o moderno. Sua

15. Ob. cit., Paris, 1837, p. 15.

16. Ibid., p. 43-4. 
conclusão, porém, é a de que ainda tinha utilidade o estudo do direito romano como elemento de esclarecimento de expressões, doutrinas e normas que o direito moderno dele herdou. Diverso, porém, era o panorama que se apresentava na Alemanha, onde o movimento codificador só triunfa no último quartel do século XIX, culminando com a entrada em vigor do Código Civil, em 1900. Nela, o estudo do direito romano, inclusive nas universidades, que, na centúria anterior, decaíra consideravelmente por influência da Escola do Direito Natural, torna a florescer com grande pujança. Isso se deveu ao movimento de reação ao jusnaturalismo e que se tornou conhecido sob a denominação de Escola Histórica. Esse movimento foi o grande adversário das codificações, sustentando que o direito não era invenção arbitrária, mas produto histórico, sendo o direito costumeiro a manifestação do Volksgeist (espírito do povo). A Escola Histórica, não só deu ênfase ao estudo histórico do direito romano, mas e esse é um ponto de contato dela com o jusnaturalismo - trouxe grande contribuição no terreno da sistematização do direito e dos conceitos jurídicos. De qualquer sorte, mesmo nos países em que as codificações surgiram mais cedo, as dúvidas sobre a utilidade prática do ensino universitário do direito romano só foram surgindo de forma lenta, pois, como observa Pugliese, ${ }^{17} \mathrm{o}$ direito romano ainda por muito tempo conservou papel importante por causa da interpretação histórica das normas dos códigos modernos e da autoridade técnico-científica sempre reconhecida às fontes romanas.

No século XX, com a entrada em vigor do Código Civil alemão, deixa o direito romano de ter interesse prático no último grande país onde ele, adaptado às necessidades sociais da época, ainda vigorava. A par disso, movimentos políticos e ideológicos sociais se voltaram contra o ensino do direito romano. Foi na Alemanha que se deu o brado de alerta para o que se denominou a crise do direito romano. Já em 1920, o ponto 19 do programa do Partido Nacional-Socialista, adotando a linha de ataque que vinha dos germanistas da centúria anterior, declarava solenemente: "Exigimos que o direito romano, que responde a uma concepção materialista do mundo, seja substituído por um direito comum alemão". Alguns anos mais tarde, em 1935, a ordenação dos estudos jurídicos na Alemanha passou a admitir que o professor pudesse 
optar entre o direito romano e a história dos direitos antigos, havendo manifesta preferência pela última dessas disciplinas. Foi nesse ambiente que Koschaker, em 1938, se levantou para alertar os romanistas da crise que se avolumara na Alemanha, e que, com intensidade maior ou menor, se verificava também em outros países, em que o estudo universitário do direito romano se voltara para o seu aspecto histórico, com ênfase, inclusive para a investigação das interpolações. No opúsculo que então escreveu, Koschaker manifestou a opinião de que, para vencer esse movimento de impopularidade, seria necessária a atualização do direito romano, simbolizada na expressão züruck zu Savigny (de volta a Savigny), e isso para dar algum interesse prático a esse estudo, certo como lhe parecia que, por ter passado o direito romano a ser estudado como estrito fenômeno histórico, se tornara antipático aos juristas modernos, e tido, de certa forma, como intruso nas Faculdades de Direito. ${ }^{18} \mathrm{Na}$ Itália, pouco depois de ser publicado o opúsculo de Koschaker, Odoardo Carrelli, ${ }^{19}$ procurou demonstrar que a crise não era científica, mas de interesse dos juristas contemporâneos pelo direito de Roma. Entendia, porém, Carrelli que não deveria adotar a proposta de Koschaker no sentido da atualização que decorria da expressão züruck zu Savigny, porquanto, se se limitassem os romanistas à simples elaboração de introduções históricas às monografias de direito moderno, em breve essa atividade se tornaria estereotipada, para desaparecer em seguida. Dessa crise se ocuparam vários outros romanistas italianos, destacando-se, dentre eles, Giuseppe Grosso, pela análise que fez dos elementos que, a seu ver, seriam adversos ao estudo universitário do direito romano: movimentos nacionalistas, como o nacional-socialismo alemão; a crise de valores de que padecem os tempos modernos, com o anti-historicismo inerente ao abstrato dogmatismo jurídico; ideologias, como a marxista; e a estreita visão da falta de utilidade prática imediata desse estudo. Na França, com a reforma dos estudos jurídicos realizada em 27 de março de 1954, nos dois anos iniciais passou-se a estudar História das Instituiçōes e dos Fatos Sociais, e, nos terceiro e quarto, para os optantes da especialização em direito privado, direito romano e antigo direito

18. Die Krise des romischen Rechts und die romanistische Rechtswissenschafi, München und Berlin, s.d., p. 83-4.

19. Apud Guarino, L'ordinamento giuridico romano, 3a ed., Nápoles, 1959, p. 13. 
francês, quanto aos bens e obrigações, aos regimes de bens do matrimônio, às liberalidades e à sucessão. Deu-se ênfase, pois, à história do direito. Em Portugal, o direito romano foi retirado do currículo universitário nos meados da década de 70, sendo, nos anos seguintes, sucessivamente reintroduzido em Coimbra e nas Universidades Católicas de Lisboa e do Porto. Na Espanha, no final dos anos 70, o projeto de Reforma General de Educación de Palasí tentou retirar o ensiro do direito romano do currículo, não o tendo, porém, conseguido pela enérgica reação a que deu margem. Em contrapartida, em países que eram avessos a esse estudo por questão ideológica, observou-se tendência contrária: voltou-se a estudar o direito romano nas universidades russas; seu ensino se intensificou na Hungria, Checoslováquia, Iugoslávia, Bulgária, Romênia, Polônia; e até na China penetraram os estudos romanísticos. No Brasil, onde, desde a instalação dos cursos jurídicos em Olinda e em São Paulo, no início do segundo quartel do século XIX, o estudo do direito romano sofreu ataques principalmente pela estreita visão da falta de sua utilidade prática imediata, o que determinou que só ingressasse no currículo do ensino superior na segunda metade daquela centúria, sofrendo seu ensino várias vicissitudes nas reformas curriculares que se fizeram, a criação de universidades, a partir da década de 30 , não fez esmorecer os ataques a ele. Em 1962, excluiu-se o direito romano das disciplinas obrigatórias do currículo das Faculdades de Direito, acentuando-se porém, que, quando não fosse colocado no curso normal como cadeira autônoma, deveria ser agregado à cátedra de direito civil, seguindo-se, de certa forma, a orientação preconizada por Koschaker. Na reformulação do currículo mínimo dos cursos jurídicos realizada no início da década de 70 , foi colocado entre as disciplinas facultativas que as Faculdades de Direito poderiam, ou não, oferecer aos alunos que desejassem estudá-lo. Tratando-se de currículo mínimo, algumas universidades o mantém como disciplina obrigatória; outras oferecem essa disciplina à escolha dos alunos; e há ainda as que não o têm no currículo obrigatório, nem o oferecem como cadeira opcional. Em 1989, a pesquisa sobre o ensino de direito romano no Brasil, feito pelo professor Agerson Tabosa, da Universidade Federal do Ceará, mostrou que, atualmente, dentre as cento e dezessete universidades e faculdades isoladas que se manifestaram, sessenta e quatro mantém o ensino do direito romano como disciplina obrigatória ou facultativa. 


\section{UNIVERSIDADE, DIREITO ROMANO E FORMAÇĀO CULTURAL.}

Nos tempos que correm, não é o direito romano aplicável como direito vigente. Por isso, seu ensino nas universidades não mais se faz mister para a formação estritamente profissional, como sucedia anteriormente, quando ele, como ius commune, se impunha na prática forense, ainda que se apresentasse como subsidiário do direito nacional. Ademais, como lucidamente observa Pugliese, ${ }^{20}$ de tal forma se aprofundou a diferença da realidade social, da economia e da tecnologia entre o mundo romano e o moderno, que a ciência jurídica, solicitada para a disciplina delas, não mais pode contentar-se com os modelos jurídicos romanos, ou deles derivados, tendo de criar outros inteiramente novos.

À semelhança do que se verificou com o latim, por haver deixado de ser a língua comum da ciência, questiona-se a utilidade do ensino do direito romano, não mais, em geral, por movimentos políticos ou por ideologias sociais, mas pela estreita visão da falta de utilidade prática imediata de seu estudo, como já na década de 40, acentuava Ursicino Alvarez Suarez:

"O direito romano constitui o humanismo dos juristas, e dele podem apregoar-se as excelências que se tributam àquele. Do mesmo modo, no direito romano repercutem os ataques dirigidos à educação clássica. $A$ polêmica existiu e existirá sempre, porque é, em última análise, a luta entre a vida prática e o ideal; porém, nāo há por que se empenhar num isolamento e numa oposiçāo radicais: o ideal é que move a vida, e esta é a que pode fazer nascer os ideais". 21

$O$ ataque ao estudo do latim, porém, se faz no plano do ensino secundário, e não no do universitário. Explica-se. Em trabalho anterior, intitulado As vicissitudes do ensino do direito romano, salientei que, no âmbito do ensino, em que essa polêmica assume maiores proporções, porque é aí que os

20. Ob. cit., p. 442-3.

21. Horizonte actual del derecho romano, Madrid, 1944, p. 44. 
partidários de uma e de outra corrente concentram esforços para moldar, segundo suas conviç̧ões, os caracteres das novas gerações, há um dado para o qual nem sempre se tem atentado devidamente:

"No conflito entre a vida prática e o ideal, há áreas culturais que, por mais que se restrinja o seu estudo nas escolas e por mais que se materialize a vida do homem moderno, sofrem menos do que outras. Por exemplo, ainda que colocado em plano secundário o ensino da estilística ou das regras da poética, não deixará de haver estilistas e poetas. Em contraposição, há setores culturais cuja sobrevivência e desenvolvimento dependem estreitamente de seus estudos nas escolas $e$ nas universidades. Basta atentar para as linguas mortas: se se não cultivam nas universidades, onde se cultivarão?"22

Esse cultivo, portanto, se impõe para que sobrevivam elementos que integram a cultura, mas que não são indispensáveis à formação cultural daqueles que não visam a tornar-se especialistas neles. Por isso, não se questiona o ensino do latim, nas universidades, em cursos superiores de línguas. $O$ mesmo, porém, não se dá, com relação a ele, no tocante ao ensino secundário, que se destina a proporcionar a formação básica do homem dentro do contexto cultural em que vive. É nesse terreno que se discute a necessidade do estudo do latim, no presente, para essa formação.

Com argúcia, Jacques Perret ${ }^{23}$ ao tratar da finalidade e do futuro do aprendizado da língua latina, adverte que, sempre que se cuida de uma reforma de ensino, volta o problema da permanência, ou não, dela no currículo escolar, principalmente por não haverem compreendido os seus defensores, que,' pela dificuldade inicial desse estudo, não podem emprestar ao latim o caráter de disciplina acessória que the resulta da defesa por meio da exaltação de suas

22: Revista da Faculdade de Direito da Universidade Federal do Ceará, Fortaleza, v.30, n.2, p. 47, jul-dez. 1989.

23. Latin et culture, Bruges, s.c.p., s.d., p. 211 e ss. 
qualidades intrínsecas (como a beleza de sua estrutura lingüística) ou das vantagens indiretas que podem ser alcançadas também por outras matérias (assim, o aguçamento intelectual pelas dificuldades de tradução de uma língua sintética). Que se diria de um geógrafo que pretendesse valorizar a geografia, dizendo que seu estudo propicia o exercício da memória, aumenta o comércio dos atlas e ensina a pronunciar palavras estrangeiras? O que se há de realçar em favor do latim, conclui Perret, ${ }^{24}$ é o que constitui a essência da finalidade de seu ensino: a iniciação ao conhecimento do mundo latino cujo espírito está presente na cultura ocidental moderna.

Nessa linha de pensamento, Braga da Cruz, ao enfrentar o tema relação do latim com o direito, frisa que tem sido erro grave de grande parte dos defensores do latim o haverem centralizado essa defesa em frutos que se recolhem indiretamente de seu estudo ou em razões de ordem prática, ao invés de destacarem a verdadeira razão por que deve ele ser estudado nos liceus, que é, pura e simplesmente, o seu interesse como elemento de formação cultural. ${ }^{25} \mathrm{E}$ arremata com estas palavras dignas de meditação:

"Segundo esta tática errada - talvez com medo de serem acusados de defender o latim por motivos de ordem ideológica -, não se aperceberam os defensores do latim que dão facilmente o flanco aos 'latinófobos', pois nāo é difícil de demonstrar que há outros meios, sem ser o latim, de aprimorar a memória, de aguçar o engenho, de criar hábitos de reflexão, rigor de expressão, disciplina mental, etc.; e, quanto ao alegado interesse prático para o cultivo de certas disciplinas em nível superior, apressam-se os 'latinófobos' logo a responder que nem sempre esse interesse é decisivo e, sobretudo, há numerosas outras disciplinas para cujo cultivo em nível superior o latim já não tem o mesmo interesse prático, devendo, ao menos para o acesso a essas

24. Ob. cit., p. 222 e ss.

25. Relação do latim com o direito. In: Obras esparsas...ob. cit., v.4, p. 512. 
disciplinas, o seu ensino ser banido dos respectivos estudos preparatórios". ${ }^{26}$

No tocante ao direito romano, a necessidade de seu ensino nas universidades, para a formação cultural dos estudantes de direito, existe não só nos países cujo ordenamento jurídico se formou com base, predominantemente, em elementos vindos dele, mas também nos em que isso não se verifica em virtude de sua elaboração histórica ou, até, de ideologias políticas e sociais.

Justificando a manutenção ou a reintrodução, no após segunda guerra mundial, do estudo do direito romano nas universidades dos países socialistas, Horvat, em artigo intitulado Lo studio del diritto romano nelle università jugoslave, se vale, principalmente, de razões de ordem cultural. Diz ele:

"Não obstante essas mudanças radicais na estrutura socialista do direito civil da nova lugoslávia, o ensino da história do direito romano e do direito romano privado foi conservado em primeiro lugar pelo fato de que o conhecimento da evolução histórica do Estado $e$ do direito é necessário a todo jurista para os fins de um aprofundamento de sua cultura jurídica",27

isso porque,

"quanto à perfeiçẫo da arte jurídica, à clareza, à lógica e coerência do pensamento jurídico, à terminologia do direito, o estudo das obras dos juristas romanos conserva grandes valores didáticos também para $o$ moderno jurisperito socialista; de feito, queremos que os

26. Relação do latim...ob. cit, v.4, p. 513.

27. Lo studio del diritto romano nelle università jugoslave. In: CONGRESSO INTERNAZIONALE DI DIRITTO ROMANO E DI STORLA DEL DIRTTTO, 27-28-29-IX-1948, Verona. Atti... Milano, 1951, v.2, p. 486. 
nossos juristas e a nossa legislaçāo se assenhoreiem complementarmente da técnica jurídica socialista" ${ }^{28}$

E, mais adiante, acrescenta:

"Embora o direito socialista iugoslavo por seu conteúdo seja diferente, de modo essencial, de cada um dos sistemas juridicos do Ocidente europeu, havendo abolido a propriedade privada dos meios de produção $e$ se orientado para a sociedade sem classes, na verdade também o direito socialista pode, em certa medida, tirar proveito da técnica jurídica, da terminologia e de toda a série de conceitos jurídicos que eram aplicados anteriormente e que, agora, no ordenamento socialista, adquirem seja um conteúdo novo, seja uma funçāo nova". 29

Pouco antes, na Rússia, o professor Pereterskij, em manual de história do direito romano, havia salientado:

"Embora não possamos reconhecer para o direito romano o valor de uma 'ratio scripta', valor atribuído a ele no passado por muitos, não podemos negar-lhe a enorme importância $e$ o fato de ter constituído um fenomeno progressista em confronto com os sistemas jurídicos anteriores. Roma criou muito de novo no campo do direito, exercendo grande influência sobre a evolução posterior do direito. Daí resulta a necessidade absoluta de estudo do direito romano e particularmente do direito romano privado. Tal direito não tem apenas valor histórico, como direito do maior Estado escravagista de que se recorda a história, mas constitui,

28. Ob. cit., p. 488.

29. Ibid., p. 489-90. 
de. per si, grande êxito histórico no campo da técnica jurídica: a precisão e a clareza, a severa lógica e a coerência do pensamento jurídico, conjuntamente com uma força vital no deduzir a conclusāo". 30

Se essas razões de ordem cultural eram reconhecidas e proclamadas nos tempos áureos do comunismo do Leste europeu, não há como negar, em países como o Brasil - onde, como dizia Braga da Cruz com relação a Portugal, não é preciso sequer explicar "o que representa a ordem jurídica vigente no quadro da cultura em que nos achamos integrados e em que medida essa cultura é tributária do legado romano ${ }^{\text {"31 }}$-, que se impõe a integração do direito romano no currículo universitário como disciplina cultural e formativa, com função antes propedêutica do que complementar, por indispensável à melhor compreensão do direito, requisito básico para que as universidades não se transformem em fábricas de meros tecnocratas jurídicos, que o mesmo Braga da Cruz, com precisão, caracterizou como "homens de leis que terão vindo do liceu sem qualquer preparação humanística e que sairão das Faculdades sem a devida compreensão da cultura em que nos achamos integrados e de que o direito que nos governa é um dos elementos fundamentais". ${ }^{32}$

A lacuna cultural decorrente de sua não-inclusão no currículo universitário é tanto mais grave quanto é exata a observação de Carnelluti, em resposta a inquérito promovido, em 1956, pela revista Labeo: para a formação cultural do jurista, é imprescindível o conhecimento do direito romano, que deveria ser estudado em duas cadeiras - uma, de instituições; outra, de Pandectas -, ainda que, para a admissão da segunda, se tivessem de retirar do currículo jurídico matérias especializadas, pois estas podem estudar-se depois da formatura, enquanto "o direito romano, ao contrário, se não se respira na Universidade, passou a ocasiāo apropriada, que não volta mais" 33

30. Apud Horvat, ob. cit., p. 489 , nota 1.

31. Relação do latim...ob. cit., v.4, p. 525.

32. Ibid., p. 502.

33. Studio e insegnamento del diritto romano (inchiesta: prima puntata). Labeo, 1956, p. 62. 


\section{BIBLIOGRAFIA}

ALVAREZ SUAREZ, Ursicino. Horizonte actual del derecho romano. Madrid, 1944.

ALVES, José Carlos Moreira. As vicissitudes do ensino do direito romano. Revista da Faculdade de Direito da Universidade Federal do Ceará, Fortaleza, v.30, n.2, jul/dez. 1989.

AZEVEDO, Fernando de. As universidades no mundo futuro. Rio de Janeiro, 1944.

CARNELUTTI, Francesco. Studio e insegnamento del diritto romano (inchiesta: prima puntata). Rivista Labeo, 1956.

CRUZ, Guilherme Braga da. Origem e evolução da universidade. In: Obras Esparsas: estudos doutrinários e sociais. Coimbra, 1985. v.4.

----. O problema da universidade. In: Obras Esparsas: estudos doutrinários e sociais. Coimbra, 1985. v.4.

-.-.-. Relação do latim com o direito. In: Obras Esparsas: estudos doutrinários e sociais. Coimbra, 1985. v.4.

DE DIEGO. Introducción al estudio de las institutiones de derecho romano. Madrid, 1900.

ENGELMANN. Die Wiedengeburt der Rechtskultur in Italien durch die wissenschaftliche Lehre. Leipzig, 1939.

FRANCA, Leonel. A crise do mundo moderno. $2^{\text {a }}$ ed. Rio de Janeiro, 1942.

FREYRE, Gilberto. In: AZEVEDO, José Carlos de Almeida. Omissão da universidade? (prefácio) Rio de Janeiro, 1978.

GUARINO, Antonio. L'ordinamento giuridico romano. $3^{\mathrm{a}}$ ed. Nápoles, 1959.

HORVAT. Lo studio del diritto romano nelle università jugoslave. In: CONGRESSO INTERNAZIONALE DI DIRITTO ROMANO E DI STORIA DEL DIRITTO, 27-28-29-IX-1948, Verona. Atti... Milano, 1951. v.2.

KOSCHAKER, Paul. Europa und das Romische Recht. München und Berlin, 1953.

ORTEGA Y GASSET. El libro de las misiones. 5ª ed. Buenos Aires : Mexico, 1950.

PERRET, Jacques. Latin et culture. Bruges, s.c.p., s.d. 
PUGLIESE, Il significato dell'insegnamento del diritto romano oggi. In: Romanitas, 1970. v. 9.

SCHAKER. Die Krise des romischen Rechts und die romanistische Rechtswissenschaft. München und Berlin, s.d.

SOHM-MITTEIS-WENGER. Institutionen (Geschichte und System des Romischen Privatrechts). Berlim, 1949.

VEYRÈRES, Bravard. De l'étude et de l'enseignement du droit romain et des résultats qu'on peut en attendre. Paris, 1837. 